Др Радомир Ј. Поповић

\title{
ПИСАРИ У СРБИЈИ У ВРЕМЕ ПРВОГ СРПСКОГ УСТАНКА 1804-1813. ГОДИНЕ
}

\begin{abstract}
У раду је анализирано порекло и положај писара у Србији за време Првог српског устанка (1804-1813). Указано је на то да су у првој години устанка писари потицали са територија захваћених устанком, да су од 1805. превладали писари рођени у Хабзбуршкој монархији. Посебну категорију чинили су свршени ученици Beлике школе који су 1812. послати у разне канцеларије као писари и секретари. На примеру устаничког ћате Нићифора Нинковића приказана је материјална несигурност писара у револуционарној држави. Указано је на огромне језичке и правописне разлике устаничких аката, као огледала (не)писмености писара.

Кључне речи: писари, Први српски устанак, Правитељствујушчи совјет, магистрати, пречани.
\end{abstract}

Писарска служба током Првог српског устанка није била предмет посебних историографских истраживања (Мереник 2004). Недостатак писаних извора на српском језику из тог времена један је од важнијих разлога зашто се о овој теми није Писало (Први СРПСКИ УСТАНАК. АКТА И ПИСмА 1977: 32-38). Други разлог је тај што су се истраживачи, због милитаристичког карактера устаничке Србије, више бавили војним установама, војводском влашћу и биткама, а опортуно запостављали, условно речено, мале теме. Међутим, када се има у виду чињеница да је на почетку 19. века становништво у Србији било неписмено, а писари малобројни, увиђа се значај писмених људи у целокупном државном устројству устаничке Србије. За циљеве Првог српског устанка писари су били једнако важни колико џебана и топови. У овом раду указаћемо на порекло, образовање и статус устаничких писара, уверени да ова тема заслужује опширну студију.

Потреба за писарима нарочито је била изражена на почетку Устанка, када је требало успоставити везу између побуњених крајева. У народној песми Почейак буне ирройив gахија сликовито је описан почетак устанка: 
„На све стране Ђорђе књиге посла (подвукао Р. П.) / У свих градских седамн’ест нахија / На кметове селске поглаваре: / Сваки свої убијие субащу / Жене,

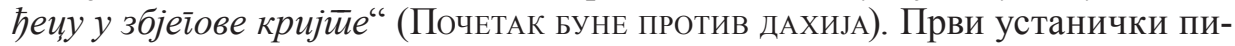
сари или ћате, како се у изворима помињу, били су пореклом с територија захваћених устанком. Радило се о личностима које су се у предустаничком периоду нередовно описмењавали у манастирима, код приватних учитеља или у приватним школама. Писар и секретар вожда Карађорђа од збора у Орашцу 1804. године до пропасти Србије 1813. године био је Јанићије Ђурић (1779-1850). Рођен у Страгарима, Ђурић се описменио у оближњем манастиру Благовештење. Са Карађорђем се упознао неколико година пред устанак, а током устанка стекао је знатан политички утицај, па је као Карађорђев секретар и повереник био упућиван у дипломатске мисије (АРСЕНИЈЕВИЋ БАТАЛАКА 1979: 68-69; Милићевић 1888: 158). Ђурићу, најистакнутијем вождовом писару и секретару, касније су се придружили Панта Радовановић, родом из Ковина, Стеван Јевтић, пореклом из Јужне Угарске, Стојан Ненадовић из шумадијског села Кличевца, Милан Марковић из Тополе, и Стеван Филиповић из Руме (НЕнадовић 1971: ХХХ; ДЕЛоводни протокол 1988: 27-30). И писари војвода̂ и устаничких четовођа у првој години устанка били су, углавном, с простора јужно од Саве и Дунава. Анта Протић (1787-1854), син смедеревског проте, школу је учио код приватних учитеља и калуђера у Смедереву и, будући да је био писмен, постао је најпре писар смедеревског војводе Ђуше Вулићевића, а потом војвода̂ Вујице Вулићевића и Стојана Чупића (АРсенијевић БАТАЛАКА 1979: 214; МилићЕвић 1888: 574). Писар хајдучког харамбаше Ђорђа Ћурчије у побуњеном Јадру 1804. године постао је Вук Караџић (1787-1864), који је, као што је добро познато, основна знања из читања и писања најпре стекао од рођака Јевте Савића Чотрића, да би своје школовање наставио у приватној школи у Лозници, а потом при манастиру Троноши (СБР 4 2009: 862-863). Ћата војводе Васе Чарапића звао се Мита, али о њему немамо других података (Милутиновић САРАлЛијА 2003: 53). Било је на почетку устанка, наравно, ћата пореклом „из прека“. Јован Манојловић Тишлер, писар војводе Луке Лазаревића, у Шабац је дошао у време Кочине крајине. Крајем 18. и почетком 19. века био је приватни учитељ у тој вароши, а током 1807. и 1808. године писар Луке Лазаревића и Шабачког магистрата (СБР 5 2011: 841; ПроТОКОЛ и РЕГИСТАР ШАБАЧКОГ МАГИСТРАТА 2010: 9). Осим Лаика, Писари су били и свештеници. Милоје Поповић Ђак из Кусадка (? -1825), у историји познат као предводник буне против кнеза Милоша 1825. године, на почетку Првог српског устанка скинуо је мантију и као писар служио код војводе Вујице Вулићевића (Милићевић 1888: 149-150; Ненадовић 1971: ХХІІ).

После почетних успеха устаника 1804. године, успостављањем централне и локалне управе (1805. године основан је Правитељствујушчи совјет, од 1807. године оснивају се магистрати по нахијама) потреба за писарима и секретарима постала је још већа. На историјску сцену тада су ступили Срби из суседне Хабзбуршке монархије. Они с вишим образовањем постали су секретари Правитељствујушчег совјета, од 1811. године и министарстава, 
док су се они с основном школом ухлебили у магистратима. Први секретар Совјета од 1805. до 1807. г. био је Божидар Грујовић, иначе Теодор Филиповић (1776-1807). Основну школу учио је у Руми, а лицеј у Шопроњу, Сегедину у Пожуну (Братислави). Права с докторатом завршио је у Будиму 1803. године. Грујовић је заслужан за писање првих уредби о устројству Правитељствујушчег совјета, као других прописа који су се односили на управу и правосуђе. Према речима Вука Караџића, Грујовић је у Совјету био „и председник, и секретар, и писар и све“. (АРСЕНИјЕВИЋ БАТАЛАКА 1979: 256; НЕнадОВИЋ 1971: Х; СБР 2 2006: 855; КАРАџИЋ 1969: 57). Секретар Совјета, после Грујовићеве смрти постао је Иван Југовић (1772-1813), који је ту дужност обављао од 1807. до 1808. године, и од 1811. до почетка 1813. године. Југовић је био један од најученијих људи свог доба. Школовао се у Сомбору, месту рођења, и Пешти. Говорио је шест језика (СБР 4 2009: 753-754). Јеремија Гагић (1781-1856), истина, није стекао високо образовање, имао је завршену основну школу, али је као други секретар Совјета од 1807. до 1808. године, пошто је знао руски језик, упућиван у дипломатске мисије. После отпуштања из службе Југовића и Гагића, секретар Совјета постао је јануара 1808. године Стефан Живковић Телемак (1780-1831), али је и он исте године протеран из службе (СБР 3 2007: 794-795). Секретари Правитељствујушчег совјета били су потом Мијаило Грујовић, брат Боже Грујовића, и Стеван Филиповић - једно време и вождов лични писар. На Народној скупштини у Београду 1811. године спроведена је реформа државне управе. Извршни орган Правитељствујушчег совјета чинило је шест министара. Остали совјетници чинили су Велики (вилајетски) суд, највишу судску инстанцу у Србији. За секретаре Великог суда постављени су Срби из Аустрије - Гаврило Вујановић, који је на ту дужност именован 8/20. фебруара 1811. године, и Гаврило Николајевић (НовАковић 1907: 83; НенАдовић 1971: ХІ).

Писари и секретари имали су значајну улогу у раду магистрата, управних и судских органа устаничке Србије. У последњој години Првог српског устанка магистрати су постојали у Београду, Неготину, Кладову, Поречу, Пожаревцу, Смедереву, Гроцкој, Ваљеву, Гургусовцу (Кнежевцу), Параћину, Ћуприји, Јагодини, Чачку, Карановцу (Краљеву), Брусници (Рудничка нахија), Ужицу, Шапцу, Лозници и Баурићу (Соколска нахија) (Дьловодный протоколь 1848: 180-184). Писар у магистрату, према уредби из 1811. године, био је дужан „свако пресужденије у протокул ставити, и ниједно незаписано оставити, пак, и давуџији и оптуженому, писмено пресужденија дати да по дрУГИ Пут не досађују“ (ПрОТОКОЛ и РЕГИСТАР ШАБАЧКОГ МАГИСТРАТА 2010: 224). Секретари Београдског магистрата били су Неша Н., Василије Матијашевић, а писари Максим Ранковић и Лазар Поповић (Ненадовић 1971: XII). У Крагујевачком магистрату као писари помињу се Милош Н. и Јован Илић (Ненадовић 1971: XXIX), а у Ваљевском магистрату: поп Мата Ђорђевић из Близоње, Сава Н. из Купинова, а као секретар - Петар Новаковић из Осека (НенАдовић 1971: XXXV). У Шабачком магистрату писари су били горе поменути Јован Манојловић и Лазар Теодоровић. Лазар Теодоровић рођен је 
у Каони у Шабачкој нахији 1781. године. Са школовања у Сремским Карловцима вратио се 1805. године и до краја Првог српског устанка учествовао је у власти у Шабачкој нахији (МилићЕвић 1888: 715; Протокол и РЕГистАР ШАБАЧКОГ МАГИСТАТА 2010: 9). При крају Устанка, секретари Шабачког магистрата били су Димитрије Костић (Константиновић) из (Сремске) Митровице и Михаило Димитрић (Поповић 2011: 45-54).

Први писари устаничке Србије били су, дакле, „домородни синови“. Од 1805. године све је више писара пореклом из Аустрије, а при крају устанка, у надлештва су за писаре послати свршени ђаци Велике школе. Наиме, на иницијативу Ивана Југовића у Београду је 1808. године с радом почела Велика школа. Њу су похађала деца устаничких старешина и штићеници утицајних људи. У лето 1812. године, после завршене Велике школе, на писарске и секретарске дужности послати су: Стојан Ненадовић - у Тополу за вождовог писара, Стефан Новаковић - за писара у Совјету, Максим Ранковић и Лазар Поповић - за писаре Београдског магистрата, Радован Дољанчевић и Павле Поповић - за писаре Великог Суда, док је Гаврило Поповић најпре именован за писара на Ђумруку Шепачка ада на Дрини, да би 1813. године био премештен у канцеларију Младена Миловановића (АРсенијевић БАТАЛАКА 1979: 398).

Према неким проценама током Првог српског устанка било је ангажовано ,једва стотинак“ писара (Луковић 1994: 42).

У средини у којој је становништво и устаничко вођство било неписмено, писари су подозревани за закулисне радње, што се одражавало на њихову личну безбедност и материјални положај. Ништа није било лакше него сменити или протерати писара из службе. У нарочито несигурном положају налазили су се писари и секретари Правитељствујушчег совјета. Јеремија Гагић, који је као секретар Совјета посредовао и преводио током преговора између Карађорђа и руског изасланика маркиза Пауличија у лето 1807. године, смењен је крајем исте године јер је, према вождовом мишљењу, више подржавао руске него српске интересе. После протеривања из службе, Гагић је постао писар војводе Миленка Стојковића, да би са њим, као противник вожда Карађорђа, напустио Србију 1811. године. Каријеру је завршио као руски конзул у Дубровнику (ПЕРовић 1980: 65-76). Иван Југовић је из службе у Совјету два пута отпуштан, крајем 1808. и почетком 1813. године, због наводног аустрофилства. Заједно са Југовићем јануара 1813. године, на изричиту заповест врховног вожда, отпуштен је и други секретар Совјета Мијаило Грујовић (ГРАЂА ИЗ ЗЕМУНСКИХ АРХИВА 1969: 402).

Неколико записа у Карађорђевом деловодном протоколу из 1812/1813. године показује несигурност положаја нижих писара. Магистрату у Крагујевцу у јулу 1812. године из Карађорђеве канцеларије (Н० 855) наређено је да писара Јову „изтерају а за писара да приме Милоша, Савина сина из Транве“ (ДЕЛОВОДНИ ПРОТОКОЛ КАРАЂОРЂА ПЕТРОВИЋА 1988: 59). У септембру 1812. г. (Но912) наређено је Алекси Дукићу, Карађорђевом момку, „да держи ћату јагодинскога за време и да уређује онако како што му је речено и по настављенијУ (...)“(ДЕЛОВОДНИ ПРОТОКОЛ КАРАЋОРЂА ПЕТРОВИЋА 1988: 64). ПоводОМ 
жалби војводе Вула Илића Коларца на рад чланова магистрата у Смедереву, Карађорђе је 30. марта 1813. године обавестио Совјет да је Коларцу наредио да смени члана магистрата, извесног Радивоја и писара магистратског, „а на њиово место да друге из вилајета поста[ви] с договором Вујице Господара“ (ДЕЛОВОДНИ ПРОТОКОЛ КАРАЂОРЂА ПЕТРОВИЋА 1988: 97). Карађорђе је јула 1813. године $\left(\mathrm{H}^{\circ} 1671\right)$ похвалио попечитеља Симу Марковића што су по његовом налогу „... протерали градскога писара који је из Немачке прешао, и наместо његово нашега (из Србије родом; прим. Р. П.) писара поставили“ (ДЕловодни ПРОТОКОЛ КАРАЂОРЂА ПЕТРОВИЋА 1988: 149). Однос устаничких старешина према писарима који су дошли из прека, био је сличан односу какав је према пречанима у Кнежевини Србији средином 19. века имала политичка групација окупљена око Томе Вучића Перишића. Сматрало се да писмени и школовани Срби из Аустрије узурпирају државне положаје и настојало се да се служба даје људима рођеним у Србији. Архимандрит Сава Петровић, који је рођен око 1792. године у Баточини и који је око две године „учио књигу“ у манастиру Миљково, постао је писар 1808. године. Када је Карађорђе сазнао да је писмен, позвао га је преда се: -,Ђаче, запиши које име да види писар Јанићије из Страгари“. Када је Сава нешто написао, а Јанићије потврдно климнуо главом, примљен је за писара и послат је на фронт на Морави (ГРАЋА ЗА ИСТОРИЈУ ПРВОГ СРПСКОГ УСТАНКА 1954: 127).

О животу писара у Србији за време Првог српског устанка сведочи у мемоарима Нићифор Нинковић, потоњи берберин кнеза Милоша. Нинковићеви мемоари, који су надалеко познати по опором опису личности кнеза Милоша и његове владавине, једнако су важни и за историју Првог српског устанка. Н. Нинковић, који је рођен у Добринацима у Срему, подстакнут ослободилачком борбом у Србији, као деветнаестогодишњак дошао је у Београд 1807. године. Будући да је био писмен, пошто је од Правитељствјушчег совјета затражио службу, постављен је за писара кнеза Илије Марковића, саветника из Шабачке нахије, који је с породицом живео у Београду. Око две године служио је као писар и учитељ Марковићеве деце. „Но ја сам пре молио кнеза (Илију Марковића; прим. Р. П.) да ми нађе једног војводу да и ја одем на војску да ми се не подсмевају наши Србљи нити укоравају: - Гди си ти проливао крв на војсци, па да смеш и ти нешто говорити!“ Жељан да се опроба у рату, Нинковић је као писар ступио у службу код војводе Максима Рашковића у Старом Влаху. Око годину и по Нинковић је провео у југозападној Србији, „ваши једући, глад трпљећи“ (ГРАЋА зА истоРију Првог СРПског УстАнКА 1954: 92). Пошто му ајлук није био месецима исплаћен (дуг војводин према Нинковићу нарастао је на 300 гроша), и када је сазнао да му војвода због дуга ради о глави, Нинковић је потајно, уграбивши две пушке и нешто барута, утекао од војводе и дошао у Београд. Пошто је без дозволе напустио претпостављеног и при томе узео наоружање и муницију, Нинковићу је суђено у Совјету. Младен Миловановић се залагао за најстрожу казну, али је Доситеј Обрадовић стао у Нинковићеву одбрану речима да ће се, ако се побију сви писари, „после земљу с рабошем држати. А никаква земља с 
рабошем нити се држала нити се држати могла!““(ГРАЋА ЗА историју ПРвоГ СРПСКОГ УСТАНКА 1954: 98). Убрзо после ослобађајуће пресуде Нинковић се обрео у Делиграду, прво као војник, па као писар Цветка бимбаше. У зиму 1809/1810. године Нинковић је унајмљен за писара кнеза Милије Здравковића у Ћуприји за месечну плату од 30 гроша. После неколико месеци је отпуштен јер је син кнеза Милије заузео његово место. „Ћато“- обратио се кнез Милија Нинковићу - „будући мој је Милосав из школе изишао и књигу научио тако ја њега задржавам при мени уместо тебе. И волем мој син да ме служи но туђин. А ево тебе исплаћујем, па тражи себи ксмет“ (ГРАЋА ЗА истоРИју ПрВОГ СРПСКОГ УСТАНКА 1954: 108). Нинковић се вратио у Београд и, молећи за службу, Совјет га је поставио за писара у Магистрату смедеревском. После неколико месеци, због сукоба с кнезовима магистрата и војводом Вулом Илићем Коларцем, опозван је и поново испитиван у Совјету. Нинковић је последњи ангажман као писар, при крају Устанка, заједно са писарем Јованом Белачевићем, имао код војводе Кара Марка Васића у Соколској нахији. „Мој Кара Марко за ручком једнако псује писаре и ружи говорећи: да је икако могућно у рабош аброве и рачуне господару предавати се могу никад не би писара код себе држао; они су такви, они су онакви, сви писари зли и неваљали људи!“ (ГРАЂА ЗА ИСТОРИЈу ПРВОГ СРПСКОГ УСТАНКА 1954: 117). Нинковић је после такве тираде споразумно напустио претпостављеног и убрзо после тога и Србију.

Последица различитог образовања устаничких писара, односно њихова општа писменост, одразила се на неуједначеност језика којим су документа писана. Сачувана акта из Првог српског устанка писана су на народном, црквенословенском и славеносрпском језику. Акта намењена унутрашњим потребама устаничке државе највећим делом су на народном језику (или с врло мало рускословенских и руских језичких црта). Ти акти имају, бар у почетку, неусиљени разговорни начин саопштавања (Ивић - КАшић 1981: 317; Луковић 1994: 43). Наведеном закључку додали бисмо да су документа на почетку устанка писали писари рођени у Србији, којима је од стране претпостављених „диктирано у перо“, па отуда неусиљен и разговорни тон у тим актима. Развојем Устанка и пријемом образованих Срба из Аустрије у канцеларије установа устаничке државе, приметни су у већој мери рускословенски и славеносрпски језички изрази, првенствено у актима која су упућивана иностраним званичницима. На народном језику, без језичких примеса црквенословенског и славеносрпског језика написани су Законик Пройе Мат̄ије Ненаgовића и Карађорђев закон. Са друге стране, паралелно с повећаним упливом учених Срба из Аустрије на државне послове устаничке Србије, акта којима је реформисана државна управа 1811. године и која је саставио поменути Мијаило Грујовић обилују русизмима и словенизмима. У полемици између Вука Караџића и М. Грујовића, поводом језичког стила пристутног у устаничким документима, а која се повела неколико година после слома устанка, Вук наводи да су Руси захтевали да се акта пишу на народном језику, која ће њихови преводиоци превести, а не на хибридном 
језику који је свима неразумљив (Луковић 1994: 46-47). Карађорђево писмо руском команданту П. В. Чичагову 25. јула / 6. августа 1812. године, у којем га обавештава о упућивању српске делегације на преговоре у Цариград, писано је мешовитим - славеносрпским језиком (ПЕРвоЕ СЕРБскОЕ ВоСтАнИЕ 1983: 267).

Акта настала у Првом српском устанку, генерално, одраз су општег стања у писаном језику тог времена које, са становишта савременог правописа, карактерише одсуство норме, то јест недоследна примена знакова интерпункције, чак и њихово одсуство, одвојено односно састављено писање речи, неуједанчено писање властитих именица, употреба различитих знакова за обележавање исте гласовне вредности. (МлАденовић 1979: 95-127). Ипак, на основу рукописа и садржаја малобројних сачуваних устаничких аката може се посредно закључити који је писар био више, а који мање образован и вешт у писању.

Писари су у огромној већини после пропасти Првог српског устанка напустили Србију. Поједини су се после емиграције вратили у земљу. Лазар Теодоровић је од 1819. године до смрти 1846. године обављао важне дужности (секретар кнеза Милоша, командант Подринско-савске команде, члан Савета и капућехаја). Јанићије Ђурић од повратка у Србију 1830. године до пензионисања 1842. године био је судија неколико окружних судова, а на крају члан Савета - највише установе Кнежевине Србије. Мијаило Грујовић је од повратка у земљу 1834 . до смрти 1842 . године, попут Ђурића, био судија окружних судова и потом члан Савета (СБР 2 2006: 856). Нићифор Нинковић се од 1819. године у Србији посветио берберском занату, а Сава Петровић се замонашио. Секретар Шабачког магистрата Димитрије Костић (Констатиновић) се 1813. године вратио у Митровицу, где се посветио трговини. Године 1868. предао је Теофилу Димићу на чување оригинални документ из Првог српског устанка Учрежсеније суgа за Шабаи и Шабачку нахију оg 12. јануара 1811. іо оине који се данас чува у Матици српској (Поповит 2011: 46-47).

\section{ИЗВОРИ}

ГрАЂА Из ЗЕМУНСКИХ АРХИВА III, 1810-1813. Београд: Историјски архив Београда, 1969. ГРАБА ЗА ИСТОРИЈУ ПрвоГ СРПСКОГ уСТАНКА. Радослав Перовић (ред.). Београд: Публицистички завод Југославија, 1954.

Дьловодный протоколь оgъ 1812. Мая 21. gо 1813. Авїусйа 5. Кара-Ђорђа Пеӣровића, врховноїъ вожяа и йосйоgара нароgа срйскоїъ. Београду: Друштво србске словесности, 1848.

ДЕЛОводни ПРОтокол КАРАЂОРЂА ПЕТРОвИЋА. Миле Недељковић (прир.). Предговор Радован Самарџић. Крагујевац - Топола: Светлост; Центар за културу Душан Петровић Шане, 1988.

КАРАџић, Вук Стефановић. Исйоријски сйиси II. Сабрана дела Вука Стефановића Караџића XVI. Београд: Просвета, [1969]. 
Первое СеРБСКое восстание 1804-1813. г2. и Россия. Книга вторая 1808-1813. Москва:

Издательство Наука, 1983.

ПрВИ СРПСКИ УСТАНАК: АКТА И ПИСМА НА СРПСКОМ ЈЕЗИКу. Књ. 1 (1804-1806). Радослав Перовић (ред.). Београд: Народна књига, 1977.

ПРОТОКОЛ И РЕГИСТАР ШАБАЧКОГ МАГИСТРАТА og 1808. go 1812. ìoguнe. Радомир J. ПоПовић (прир.). Београд: Историјски институт, 2010.

ПочЕТАК БУНЕ ПРОтИв ДАХИјА <https://www.nb.rs/collections/index.php?id=1913> 12.3.2021.

\section{ЦИТИРАНА ЛИТЕРАТУРА}

АРСенИјевИЋ БАТАЛАКА, Лазар. Ист̄орија срӣской устианка I. Београд 1898. Београд: Слово љубве, 1979.

Ивић, Павле, Јован КАшић. О језику код Срба у раздобљу од 1804. до 1878. године. Ист̄орија срӣской нароga V-2. Београд: Српска књижевна задруга, 1981.

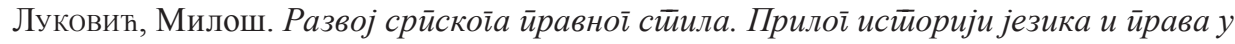
Србији. Београд: Службени гласник, 1994.

МЕРеник, Славица. Библиоірафија раgова о Срӣској револуичији. Београд: Завод за уџбенике, 2004.

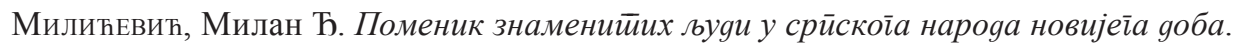
Београд, 1888. Београд: Слово љубве, 1979.

Милутиновић САРАллија, Сима. Житијја устианика. Милорад Радевић (прир.). Коцељева: Библиотека Јанко Веселиновић, 2003.

МлАденовић, Александар. Напомене о транскрипцији и критичком издавању старих српских текстова из XVIII и XIX века. Зборник за филолоїију и линіивстиику Майице срйске XXII/2 (1979), 95-129.

Ненадовић, Константин. Живот̄ и дела Карађорђа и њеі̄ови војвоgа и јунака II. Беч, 1884. Београд: Слобода, 1971.

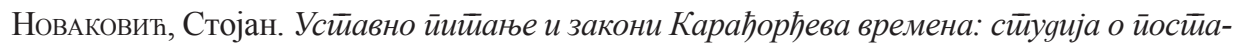
юу и развићу врховне и среgищне власт̄и у Србији 1805-1811. Београд: Давидовић, 1907.

Перовић, Радослав. Прилози за срӣску ист̄орију. Београд: Слово љубве, 1980.

Поповић, Радомир Ј. Димитрије Костић (Константиновић) - устанички писар и митровачки трговац. Сйоменица Ист̄оријской архива Срем 10 (2011), 45-54.

СБР 2: Срӣски биоїрафски речник 2. В-Г. Нови Сад: Матица српска, 2006.

СБР 3: Срйски биоірафски речник 3. Д-3. Нови Сад: Матица српска, 2007.

СБР 4: Срйски биог̄рафски речник 4. И-Ка. Нови Сад: Матица српска, 2009.

СБР 5: Срӣски биойрафски речник 5. Кв-Мао. Нови Сад: Матица српска, 2011.

ТЕодоровић, Лазар. Карађорђево Известіє о Сербіи и последньимъ догађаима србскогъ (новіегъ) доба као и о првыма за тымъ слһдуюћима. Гласникъ Друшишвва србске словесностии 4 (1852), 152-184. 
Radomir J. Popović

\section{SCRIBES IN SERBIA DURING THE FIRST SERBIAN UPRISING \\ 1804-1813}

\section{Sum mary}

An important segment in the state organization of Serbia during the First Serbian Uprising were scribes. In terms of origin, we differentiate scribes born in Serbia, who were educated in monasteries or with private tutors, and scribes from Austria, who had regular primary or even higher education. Austrian scribes with higher education were the secretaries of the Governing Council (Boža Grujović, Ivan Jugović, Mijailo Grujović...) and those with a completed primary school were scribes with dukes and in magistrates. At the beginning of the Uprising the majority of scribes were from Serbia. From 1805 until the end of the First Serbian Uprising the majority of scribes were from Austria. The need for a larger number of scribes occurred during the establishment of the institutions of central and local government: of the Council in 1805, of the magistrate in 1807 and of the Great School in 1808. The first generation of the graduates of the Great School in 1812 were sent to various offices of the rebel state. It is estimated that during the First Serbian Uprising around a hundred scribes worked in Serbia. The paper presents the insecurity of the position of the scribe using the example of Nićifor Ninković, who served six employers in the period 1807-1813. Some scribes from the First Serbian Uprising played an important role in state administration of Serbia during the reign of Prince Miloš and constitutional defenders (Lazar Tedorović and Janićije Đurić).

Историјски институт Беооград

Кнез Михаилова 3611000 Београд

rjpopovic@gmail.com 